\title{
Tall Stature and Poor Breast Development after Estrogen Replacement in a Hypergonadotrophic Hypogonadic Patient with a 45,X/46,X,der(X) Karyotype with SHOX Gene Overdosage
}

clinical case report

\author{
MIRIAN YUMIE NISHI \\ Rafaela Vieira Correa \\ elaine Maria Frade Costa \\ ANa Elisa Correia BILLERBECK \\ ANDRÉ LUIS CRUZES \\ SORAHIA DOMENICE \\ Luciani Renata Carvalho \\ BERENICE B. MENDONCA
}

\begin{abstract}
SHOX is exclusively expressed in the developing distal limb bones of human embryos and in the first and second pharyngeal arches. It works as a promoter for linear growth and as a repressor of growth plate fusion. It was reported, recently, that $S H O X$ overdosage and gonadal estrogen deficiency have led to tall stature due to continued growth. We report, in the present study, a female patient with $45, X / 46, X$, psu idic $(X)(p t e r \rightarrow q 21:: q 21 \rightarrow$ pter) karyotype, tall stature, and hypergonadotrophic hypogonadism without Turner stigmas. She did not present breast development even after long term therapy with high estrogen doses. Fluorescence in situ hybridization depicted the presence of three copies of SHOX gene. Microsatellite studies showed paternal origin of $\operatorname{der}(\mathrm{X})$. Further studies in similarly affected patients will clarify if the absence of breast development, despite previous high-dose estrogen treatment, is associated to triple copy of SHOX gene. (Arq Bras Endocrinol Metab 2008; 52/8:1282-1287)
\end{abstract}

Keywords: SHOX overdosage; Tall stature; Gonadal dysgenesis

\section{RESUMO}

Laboratório de Hormônios e
Genética Molecular LIM/42 Unidade de Endocrinologia do Desenvolvimento, Hospital das

Clínicas da Faculdade de Medicina da Universidade de São Paulo (HC-FMUSP) (MYN, AECB, EMFC, SD, LRC, BBM), São Paulo, SP, Brasil; Universidade de Fortaleza (RVC), Fortaleza, CE, Brazil; Associação de Diabetes Juvenil da Região Noroeste Paulista (ALC), Birigüi, SP, Brasil.

Received in 25/8/2008

Accepted 16/10/2008
Estatura Alta e Hipodesenvolvimento Mamário após Reposição Estrogênica em Paciente com Hipogonadismo Hipergonadotrófico e Cariótipo 45,X/46,X, der(X) com Superdosagem do Gene SHOX.

O gene SHOX é expresso, exclusivamente, no primeiro e no segundo arcos faríngeos, assim como nas extremidades dos ossos dos membros em embriões humanos. SHOX normalmente atua como um promotor para o crescimento linear e como um repressor do fechamento da placa de crescimento. Recentemente, foi descrito que o excesso da proteína SHOX associada à deficiência estrogênica gonadal leva à estatura alta devido ao contínuo crescimento. Neste estudo descrevemos uma paciente do sexo feminino com cariótipo 45,X/46,X,psu idic $(X)$ (pter $\rightarrow$ q21::q21 $\rightarrow$ pter), estatura alta, hipogonadismo hipergonadotrófico e sem estigmas de Turner. A paciente não apresentou desenvolvimento de mamas, mesmo depois do tratamento prolongado com altas doses de estrógenos. FISH evidenciou a presença de três cópias do SHOX. Estudo de microssatélites demonstrou a origem paterna do der(X). Estudos futuros em pacientes com semelhanças clínicas esclarecerão se a ausência de desenvolvimento de mamas, apesar do tratamento com altas doses de estrógenos, está associada à tripla cópia do SHOX. (Arq Bras Endocrinol Metab 2008; 52/8:1282-1287)

Descritores: Overdosagem de SHOX; Estatura alta; Deficiência estrogênica gonadal 


\section{INTRODUCTION}

$t$ the end of short $\mathrm{X}$ and $\mathrm{Y}$ chromosome arms there is a common portion named short arm pseudoautosomal region (PAR-1) spaning 2.6 Mb. PAR-1 escapes from $\mathrm{X}$ inactivation process and recombines during male meiosis (1). Individuals with absence of this region present short stature which indicates that this region is related to growth $(2,3)$. In 1997, two different groups described, simultaneously, a gene responsible for stature, $S H O X$ ("Short Stature Homeobox-Containing Gene") $(2,3)$, located on the PAR-1. SHOX is composed by 7 exons with $40 \mathrm{~kb}$ in length (4), that encodes two different proteins, one with 292 and other with 225 amino acids due to an alternative splicing $(2,3)$. It is exclusively expressed in the first and second pharyngeal arches and in the developing distal limb bones of human embryos (5). SHOX normally functions as a promoter for linear growth and as a repressor for growth plate fusion and skeletal maturation (6). SHOX haploinsufficiency due to deletions or mutations leads to short stature and skeletal abnormalities such as in Turner syndrome, or Madelung deformity of the forearm, such as in Léri-Weill dyscondrosteosis.

Recently, patients with karyotype alterations involving sexual chromosomes resulting in $\mathrm{SHOX}$ overdosage were described in the literature (7-10). This fact associated to estrogen deficiency owing to gonadal dysgenesis seems to be the cause of excessive growth, especially in the distal limb bones, in the middle to late teenage females $(7,10,11)$.

In the present study, we report a $45, \mathrm{X} / 46, \mathrm{X}, \mathrm{der}(\mathrm{X})$ female patient with tall stature, low body mass index (BMI), no breast development or Turner's stigmata and gonadal insufficiency in whom a $S H O X$ gene overdosage was suspected.

\section{METHODS}

\section{Cytogenetic Analysis}

Chromosome metaphase spreads prepared from peripheral blood lymphocyte cultures of the patient and her parents were analyzed by conventional staining, G and $\mathrm{C}$ banding techniques. The kit Vysis ${ }^{\circledR}$ Kallman Region Probe (Vysis Inc., Abbott Laboratories, Illinois, USA) and the biotinylated LLNOYCO3"M" $34 \mathrm{~F} 5$ cosmid containing exons III to VIb of $S H O X$ gene were used for the FISH methodology. The analysis was per- formed using the Karyotyping Software Macktype v.5.4.1 and Mackprobe v. 4.0 (Perceptive Scientific Instruments Inc., UK) for FISH.

\section{Molecular Analysis}

Genomic DNA was obtained from peripheral blood leukocytes using the Salting-Out technique (12). The microsatellite study was carried out using the panel for the X chromosome presented in the kit Linkage Mapping set v.2.5 MD10 (PE Applied Biosystems, The Perkin-Elmer Corporation, CA, USA). The PCR products were submitted to electrophoresis in the ABI PRISM 310 automatic sequencer (PE Applied Biosystems, The Perkin-Elmer Corporation, CA, USA) and the analysis was made by GeneScan software (PE Applied Biosystems, The Perkin-Elmer Corporation, CA, USA).

\section{CASE REPORT}

The present study was approved by the Ethics Committee of the Hospital das Clinicas, The University of Sao Paulo Medical School. Written consent was obtained from the patient and their parents.

A 16 year-old Brazilian girl was referred due to absence of secondary sexual development. She was born at 40 weeks of gestation after an uncomplicated pregnancy, a single daughter of non consanguineous parents. At birth, she weighted $3.250 \mathrm{~g}$ and measured 52 $\mathrm{cm}$. Her growth chart showed that she grew at the $50^{\text {th }}$ percentile until 9 months of age, at the $75^{\text {th }}$ percentile from 9-33 months, and after 3 years of age at $>95^{\text {th }}$ percentile. She underwent spontaneous pubarche at 12 years, without telarche. She presented menarche at 14 years, after estrogen replacement without adequate breast development. At 16 her height was $183 \mathrm{~cm}, 20$ $\mathrm{cm}$ above her target height, with an eunuchoid habitus and her BMI was $15 \mathrm{Kg} / \mathrm{m}^{2}$. Puberty evaluation disclosed Tanner II breast development, Tanner V pubic hair and normal female external genitalia (Table 1). Basal serum hormone data revealed elevated gonadotropins $(\mathrm{LH}=40 \mathrm{U} / \mathrm{L}$ and $\mathrm{FSH}=85 \mathrm{U} / \mathrm{L})$, low estrogen levels, normal PRL, GH, IGFl and IGFBP3 levels.

\section{RESULTS}

Cytogenetic analysis showed a $45, \mathrm{X}[4] / 46, \mathrm{X}, \operatorname{der}(\mathrm{X})$ [46] karyotype (Figure 1). The parents' karyotypes study was normal. FISH analysis revealed an extra copy 
Table 1. Clinical data before and after hormonal treatment.

\begin{tabular}{|c|c|c|c|c|c|c|}
\hline $\begin{array}{l}\text { Age } \\
\text { (yrs) }\end{array}$ & $\begin{array}{l}\text { Height } \\
(\mathrm{cm})\end{array}$ & $\begin{array}{c}\text { SD } \\
\text { (height) }\end{array}$ & $\begin{array}{l}\text { Weight } \\
\text { (kg) }\end{array}$ & $\begin{array}{l}\text { Breast } \\
\text { (Tanner) }\end{array}$ & $\begin{array}{l}\text { Pubic hair } \\
\text { (Tanner) }\end{array}$ & Treatment \\
\hline 11.8 & 174.8 & +3.5 & 43 & I & IV & Conjugated estrogen $0.625 \mathrm{mg}$ \\
\hline 16.5 & 183 & +3.5 & 50 & $\|$ & V & $\begin{array}{l}\text { Valerate of estradiol } 2 \mathrm{mg} \\
\text { Levonorgestrel } 0.25 \mathrm{mg}\end{array}$ \\
\hline 16.8 & 183.5 & +3.5 & 51 & $\|$ & V & $\begin{array}{l}\text { Valerate of estradiol } 2 \mathrm{mg} \\
\text { Levonorgestrel } 0.25 \mathrm{mg}\end{array}$ \\
\hline 17 & NA & NA & NA & $\|$ & NA & $\begin{array}{l}\text { Ethnyl estradiol } 70 \mathrm{ug} \\
\text { Ciproterone acetate } 4 \mathrm{mg}\end{array}$ \\
\hline 17.5 & 184 & +3.6 & 51 & III & V & $\begin{array}{c}\text { Ethnyl estradiol } 70 \mathrm{ug} \\
\text { Ciproterone acetate } 4 \mathrm{mg}\end{array}$ \\
\hline 18 & 184.2 & +3.7 & 52 & III & V & $\begin{array}{c}\text { Ethnyl estradiol } 35 \mathrm{ug} \\
\text { Ciproterone acetate } 2 \mathrm{mg}\end{array}$ \\
\hline 18.6 & 184.4 & +3.7 & 52 & III & V & $\begin{array}{c}\text { Valerate of estradiol } 2 \mathrm{mg} \\
\text { Levonorgestrel } 0.25 \mathrm{mg}\end{array}$ \\
\hline
\end{tabular}

NA = Not available

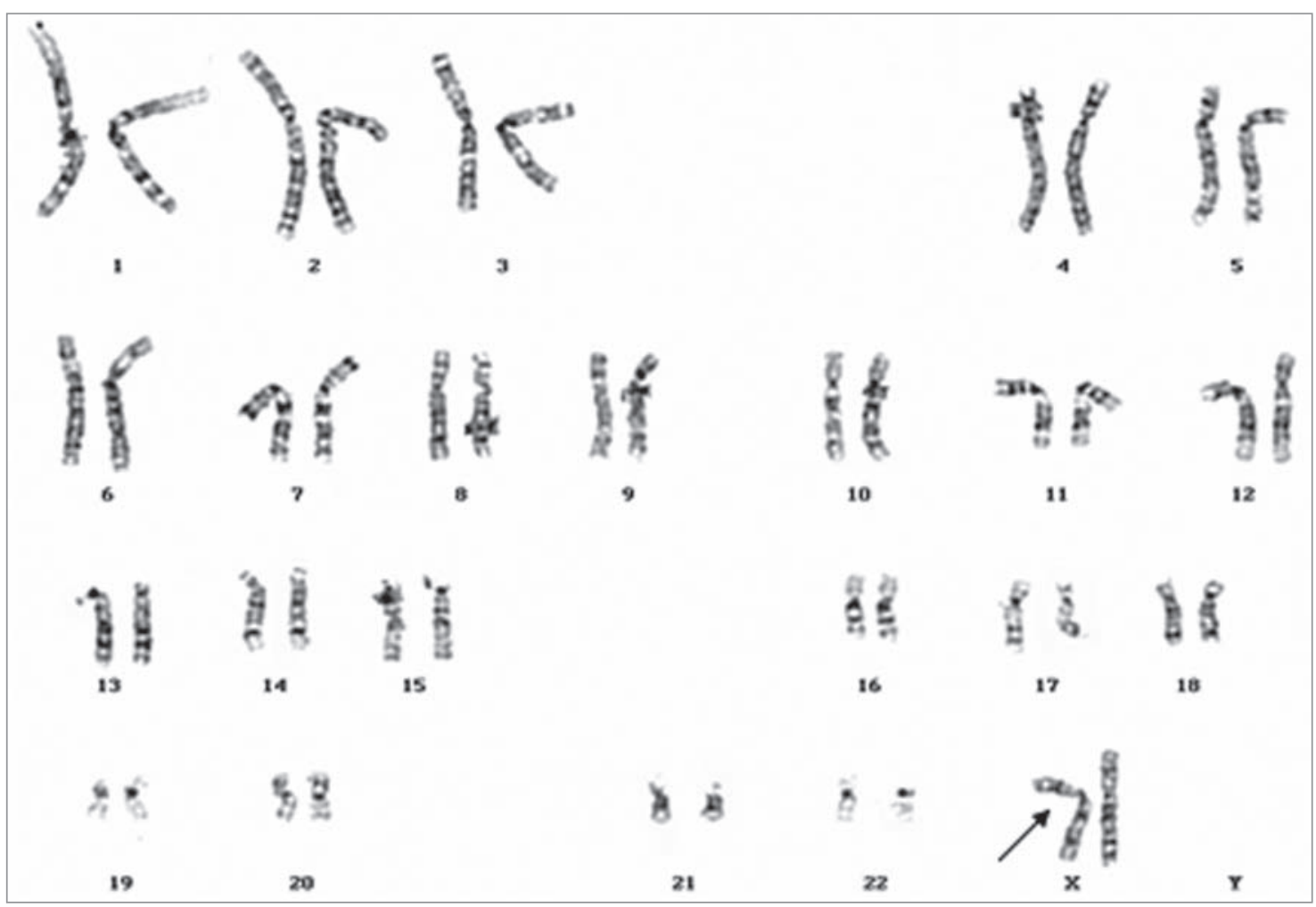

Figure 1. GTW-banded Karyotype: 46,X,psu idic (X)(pter $\rightarrow$ q21::q21 $\rightarrow$ pter). 
of $S H O X$ and KAL genes and $\mathrm{X}$ centromere (Figures 2 and 3$)$ in the $\operatorname{der}(\mathrm{X})$, showing that the $\operatorname{der}(\mathrm{X})$ is a psu $\operatorname{idic}(X)($ pter $\rightarrow \mathrm{q} 21:: \mathrm{q} 21 \rightarrow$ pter $)$. Microsatellite study revealed the paternal origin of psu idic $(X)(p t e r \rightarrow q 21:: q 21$ $\rightarrow$ pter) (Figure 4). The markers DXS991 and DXS986 localize on Xp11.21 and Xq21.1, respectively, were not informative.

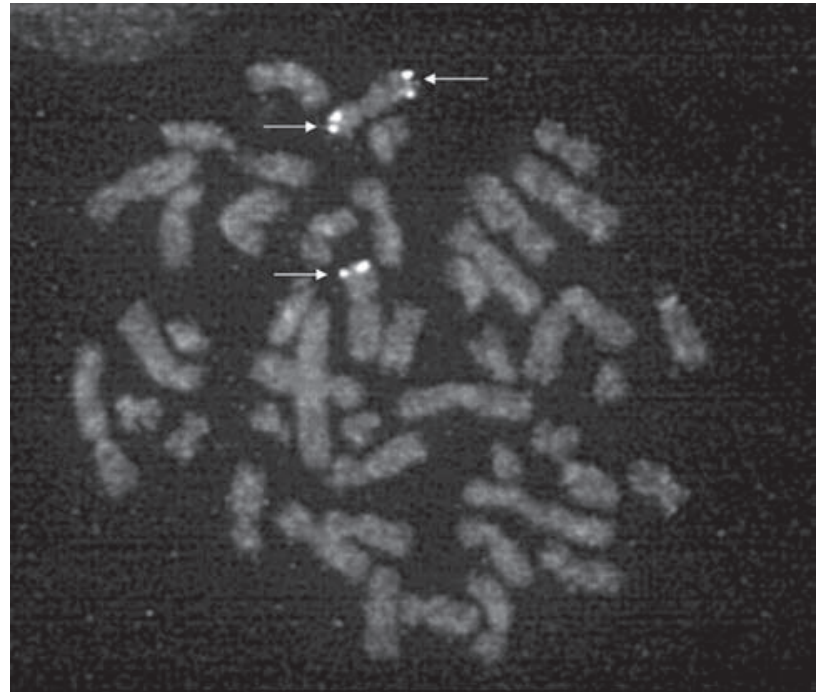

Figure 2. FISH analysis indicating triple copies of SHOX gene in metaphase chromosome

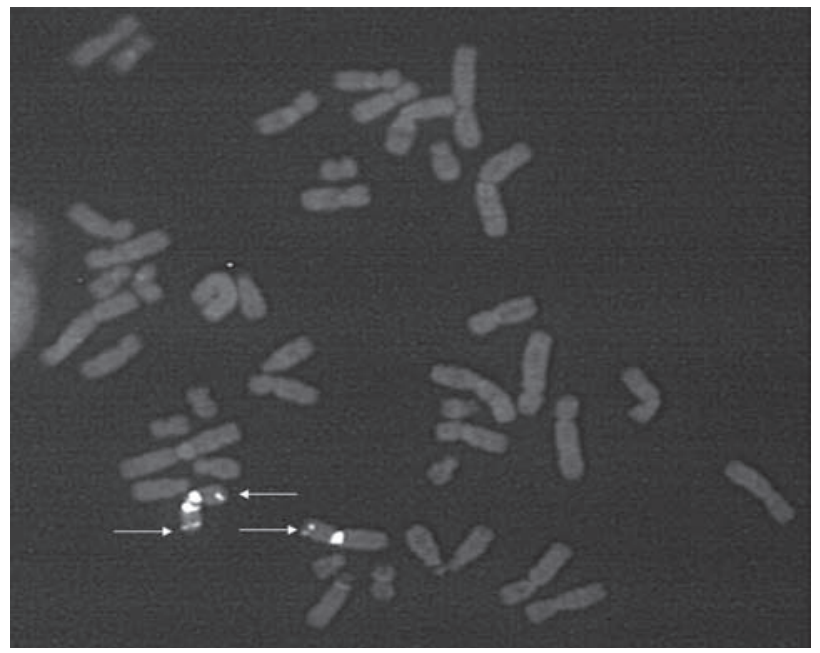

Figure 3. FISH analysis indicating DXZ1 probe hybridization to centromere (internal signal) and triple copies of $K A L$ gene (arrows) in metaphase chromosome.

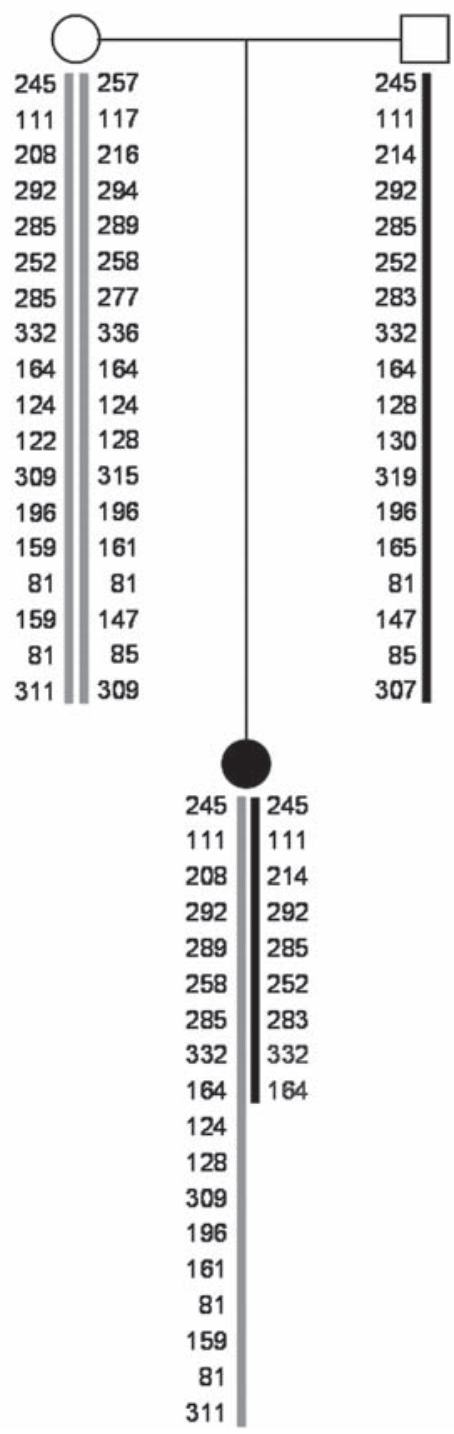

Figure 4. Heredogram of the patient with the microsatellite study indicating the paternal origin of $\operatorname{der}(X)$. The markers DXS991 and DXS986 were not informative.

\section{DISCUSSION}

Recently, it has been reported that SHOX overdosage and gonadal estrogen deficiency leads to tall adult height $(7,9)$. These findings suggest that SHOX overdosage in combination with gonadal dysgenesis leads to continuous growth since early infancy until late adolescence, since $S H O X$ functions as a repressor for growth plate fusion, in contrast with skeletal maturing effect of estrogens (10).

Here we reported a patient with a $45, \mathrm{X}[4] / 46, \mathrm{X}$,psu $\operatorname{idic}(X)($ pter $\rightarrow$ q21 ::q21 $\rightarrow$ pter $)[46]$ karyotype and go- 
nadal dysgenesis, tall stature, no Turner stigmas and poor breast development after estrogen replacement. The altered $\mathrm{X}$ chromosome has a paternal origin, which contains a partial $\mathrm{Xq}$ deletion, two centromeres and a Xp duplication resulting in an extra $S H O X$ gene.

To date, six female patients with an extra copy of SHOX gene in a der(X) were described (Table 2). Three of them had tall stature as well as the present case. However, three patients present normal height despite the extra copy of $S H O X$ associated to estrogen deficiency indicating that an extra copy of $S H O X$ is not sufficient for the development of tall stature (7-10). On the other hand, Kanaka-Gantenbein, 2004 suggested that $S H O X$ triplication per se may induce the tall stature, since their patient presented tall stature in the absence of estrogen deficiency (15). These controversial reports may be due to the fact that the mechanism of SHOX action still remains unclear.

Our patient showed poor breast development after estrogen treatment. Normally, these patients presented adequate breast development after estrogen treatment $(9,10,13)$. However, Nakamura et al. also reported a patient with gonadal dysgenesis and an extra copy of $S H O X$ who had poor breast development after estrogen therapy (8). The reason for the poor breast development in these two patients is still unexplained. Further studies in similarly affected patients will clarify if the absence of breast development despite high-dose estrogen treatment is related to the extra copy of $S H O X$ gene.

Acknowledgment: B.B.M. was supported by grant 301246/955 from Conselho Nacional de Pesquisa (CNPq). No potential conflict of interest relevant to this article was reported.

\section{REFERENCES}

1. Rappold GA. The pseudoautosomal regions of the human sex chromosomes. Hum Genet. 1993;92(4):315-24.

2. Ellison JW, Wardak Z, Young MF, Gehron Robey P, Laig-Webster $\mathrm{M}$, Chiong W. PHOG, a candidate gene for involvement in the short stature of Turner syndrome. Hum Mol Genet. 1997;6 (8):1341-7.

3. Rao E, Weiss B, Fukami M, et al. Pseudoautosomal deletions encompassing a novel homeobox gene cause growth failure in idiopathic short stature and Turner syndrome. Nat Genet. 1997; 16(1):54-63.

4. Blaschke RJ, Rappold GA. SHOX: growth, Leri-Weill and Turner syndromes. Trends Endocrinol Metab. 2000;11(6):227-30.

5. Clement-Jones M, Schiller S, Rao E, et al. The short stature homeobox gene SHOX is involved in skeletal abnormalities in Turner syndrome. Hum Mol Genet. 2000;22;9(5):695-702.

6. Munns CJ, Haase HR, Crowther LM, et al. Expression of SHOX in human fetal and childhood growth plate. J Clin Endocrinol Metab. 2004;89(8):4130-5.

7. Binder G, Eggermann T, Enders $H$, Ranke MB, Dufke A. Tall stature, gonadal dysgenesis, and stigmata of Turner's syndrome caused by a structurally altered X chromosome. J Pediatr. 2001;138(2):285-7.

8. Nakamura $Y$, Suehiro $Y$, Sugino N, Sasaki K, Kato H. A case of 46,X,der(X)(pter--\&gt;q21::p21--\&gt;pter) with gonadal dys-

Table 2. Phenotype of SHOX overdosage in female patients.

\begin{tabular}{|c|c|c|c|c|c|c|c|}
\hline $\begin{array}{l}\text { Age } \\
\text { (Yrs) }\end{array}$ & $\begin{array}{l}\text { Height } \\
(\mathrm{cm} \quad \text { SD) }\end{array}$ & HH & $\begin{array}{l}\text { Turner } \\
\text { Stigmas }\end{array}$ & $\begin{array}{c}\text { Breast } \\
\text { Development } \\
\text { (after estrogen) }\end{array}$ & Cytogenetic Data & $\begin{array}{l}\operatorname{Der}(X) \\
\text { Origin }\end{array}$ & Reference \\
\hline 29 & $172+2.9$ & Present & $\begin{array}{l}\text { Mild webbed } \\
\text { neck }\end{array}$ & $\begin{array}{c}\text { Full } \\
\text { development }\end{array}$ & $\begin{array}{c}45, X[40] / 46, X, \operatorname{der}(X)(\text { pter } \rightarrow q 13 \text { or } q 21:: p 14 \rightarrow \\
\text { or } p 21.2 \rightarrow \text { pter[60] }\end{array}$ & Paternal & $(10)$ \\
\hline 20 & $174+2$ & Present & Absent & Tanner II & $46, X, \operatorname{der}(X)($ pter $\rightarrow q 21:: p 21 \rightarrow$ pter $)$ & NR & (8) \\
\hline 20 & $161.9+0.8$ & Present & Absent & $\begin{array}{c}\text { Sufficient } \\
\text { development }\end{array}$ & 45,X[28]/46,X,psu idic $(X)(q 28)[72]$ & NR & (9) \\
\hline 20 & $166+1.5$ & Present & Absent & Normal & $46, X, \operatorname{rec}(X) \operatorname{dup} \mid(X p) \operatorname{inv}(X)(p 11.22 q .21 .2)[30]$ & Maternal & (13) \\
\hline 14 & $172+2$ & Present & $\begin{array}{l}\text { Multiple nevi, } \\
\text { high arched } \\
\text { palate }\end{array}$ & NR & 46,X,der $(X)($ pter $\rightarrow$ q21.2::p1 1.1 $1 \rightarrow$ pter $)[40]$ & NR & (7) \\
\hline 20 & NR - 1.2 & Present & Absent & NR & $\begin{array}{c}45, X[6] / 46, X, \operatorname{der}(X)(\text { pter } \longrightarrow q 21.1:: p 22.3 \longrightarrow \text { pter }) \\
{[12] / 46, X, r(X)(\text { p22q13)[2] }}\end{array}$ & $\mathrm{Nr}$ & (14) \\
\hline 16 & $183+3.5$ & Present & Absent & Tanner II & $45, X[4] / 46, X$, psu idic $(X)($ pter $\rightarrow q 21:: q 21 \rightarrow$ pter $)[46]$ & Paternal & $\begin{array}{l}\text { Present } \\
\text { Study }\end{array}$ \\
\hline
\end{tabular}

$\mathrm{HH}$ : hypergonadotropic hypogonadism; NR: not reported. 
genesis, tall stature, and endometriosis. Fertil Steril. 2001;75 (6):1224-5.

9. Ogata $\mathrm{T}$, Inokuchi M, Ogawa M. Growth pattern and body proportion in a female with short stature homeobox-containing gene overdosage and gonadal estrogen deficiency. Eur J Endocrinol. 2002;147(2):249-54.

10. Ogata T, Kosho T, Wakui K, Fukushima Y, Yoshimoto M, Miharu N. Short stature homeobox-containing gene duplication on the $\operatorname{der}(X)$ chromosome in a female with $45, X / 46, X, \operatorname{der}(X)$, gonadal dysgenesis, and tall stature. J Clin Endocrinol Metab. 2000;85(8):2927-30.

11. Ogata T, Matsuo N, Nishimura G. SHOX haploinsufficiency and overdosage: impact of gonadal function status. J Med Genet. 2001;38(1):1-6.

12. Miller SA, Dykes DD, Polesky HF. A simple salting out procedure for extracting DNA from human nucleated cells. Nucleic Acids Res. 1988;16(3):1215.

13. Adamson KA, Cross I, Batch JA, Rappold GA, Glass IA, Ball SG. Trisomy of the short stature homeobox-containing gene (SHOX), resulting from a duplication-deletion of the $X$ chromosome. Clin Endocrinol (Oxf). 2002;56(5):671-5.
14. Ogata T, Matsuo N, Fukushima Y, et al. FISH analysis for apparently simple terminal deletions of the $X$ chromosome: identification of hidden structural abnormalities. Am J Med Genet. 2001;104(4):307-11.

15. Kanaka-Gantenbein C, Kitsiou S, Mavrou A, et al. Tall stature, insulin resistance, and disturbed behavior in a girl with the triple X syndrome harboring three SHOX genes: offspring of a father with mosaic Klinefelter syndrome but with two maternal X chromosomes. Horm Res. 2004;61(5):205-10.

\section{Correspondence to:}

Mirian Yumie Nishi

Hospital das Clínicas, FMUSP, Laboratório de Hormônios e Genética Molecular LIM 42 - Disciplina de Endocrinologia Av. Dr Enéias de Carvalho Aguiar, 155, PAMB, $2^{\circ}$ andar, bloco 6 05403-900 São Paulo SP

E-mail: minishi@usp.br 